\title{
Osteocranium of Tor tambroides (Cypriniformes: Cyprinidae) from Tangse River, Aceh, Indonesia
}

\author{
YUSRIZAL AKMAL ${ }^{1, \vartheta}$, ILHAM ZULFAHMI ${ }^{2, \vartheta v}$, YENI DHAMAYANTI ${ }^{3, v \vee v, ~}$ EPA PAUJIAH $^{4, v \vee v \vee}$ \\ ${ }^{1}$ Department of Aquaculture, Faculty of Agriculture, Universitas Almuslim. Jl. Almuslim, Matang Glumpang Dua, Peusangan, Bireuen 24261, Aceh, \\ Indonesia. "email: drh.yusrizal.akmal.msi@gmail.com. \\ ${ }^{2}$ Department of Biology, Faculty of Science and Technology, Universitas Islam Negeri Ar-Raniry. Jl. Kota Pelajar dan Mahasiswa, Darussalam, Banda \\ Aceh 23111, Aceh, Indonesia. ${ }^{*}$ email: ilham.zulfahmi@ar-raniry.ac.id. \\ ${ }^{3}$ Department of Veterinary Anatomy, Faculty of Veterinary Medicine, Universitas Airlangga. Kampus C, Mulyorejo, Surabaya 60115, East Java, \\ Indonesia."vemail: yen.un41r@gmail.com. \\ ${ }^{4}$ Department of Biology Education, Faculty of Education and Teacher Training, Universitas Islam Negeri Sunan Gunung Djati. J1. AH. Nasution No. 105, \\ Cibiru, Bandung 40614, West Java, Indonesia. •rvemail: epapaujiah@uinsgd.ac.id
}

Manuscript received: 11 October 2019. Revision accepted: 5 January 2020.

\begin{abstract}
Akmal Y, Zulfahmi I, Dhamayanti Y, Paujiah E. 2020. Osteocranium of Tor tambroides (Cypriniformes: Cyprinidae) from Tangse River, Aceh, Indonesia. Biodiversitas 21: 442-450. We report the first detailed descriptive osteocranium of keureling, Tor tambroides (Cypriniformes: Cyprinidae) collected from Tangse River, Indonesia. This study aimed to describe the cranium morphology of keureling (Tor tambroides). Keureling fish used in this study were obtained from the catch of fishers in the Tangse River, District of Pidie, Aceh Province, Indonesia. Stages of research include sample preparation, bone preparations, and identification of cranium nomenclature. For osteological examination, the cranium of the keureling prepared physically and chemically. Based on the results, the cranium of the keureling is divided into two major parts, namely the neurocranium and the facial bone, $\mathrm{s}$ including the branchial apparatus. The neurocranium is divided into (anterior to posterior) olfactory (ethmoid), orbital, otic, and occipital regions while the rest divided into oromandibular, opercular series, branchial arch, mandibular arch, and hyoid arch (suspensorium) regions. The neurocranium includes bones in the dermal series of the skull and endochondral bones protecting the brain. At the same time, branchiocranium are those located in the oromandibular part, opercular series, and branchial arch.
\end{abstract}

Keywords: Branchiocranium, neurocranium, osteology, oromandibular region, Tor tambroides

\section{INTRODUCTION}

Fish have a very complex and highly kinetic skeleton (Ferry-Graham and Lauder 2001). The musculoskeletal system of cranium in an adult teleostean fish reported to consist of about 60 interconnected bones (Aerts 1991; De Iuliis and Pulerà 2011). The study of the morphology of the fish skeleton needed to understand the systematic, taxonomic and phylogenetic relationships among fish species (Eagderi and Adriaens 2014; Mafakheri et al. 2014, Jalili et al. 2015). Deschamps and Sire (2010) stated that the description of skeleton morphology is essential to identify the occurrence of abnormalities in the skeletal system. Also, the ontogeny of the skull can provide substantial information regarding the evolution of fishbone development (Bogutskaya et al. 2008).

Studies of skeleton morphology of various families of fishes have previously reported, for instance in the families Cyprinidae (Takeuchi and Hosoya 2011; Jalili et al. 2016; Nasri et al. 2016), Characidae (Bogutskaya et al. 2008), Nemacheilidae (Mafakheri et al. 2014), Cichlidae (Dierickx et al. 2017), Alestidae (Murray 2004) and the suborder Zoarcoidei (Hilton and Kley 2005). Although studies of fish skeleton morphology have conducted, skeletal constituent bone nomenclature, especially for elements of the cranium, is inconsistent, such that the compilation of bone data for different fish species may become biased (Bogutskaya et al. 2008).

Cranium has the primary function of protecting the brain and sensory organs in the head (Hilton 2011). Cranium can be divided into two major parts, the cranial (neurocranium) and facial bones (Jalili et al. 2015; Nasri et al. 2015). The shape of the cranium in each species influenced by the individual's genetics and environmental backgrounds, such as feeding habits and water quality. According to Cooper and Westneat (2009), the evolution of fish diet has a close relationship with the diverse morphologies of the maxilla and premaxilla. For example, the mouth in benthic species is generally positioned terminally or superior and with elastic lips, blunt jaws, and lacking teeth (Fugi et al. 2001). The structure of the jaw in predatory fish from the genus Dunkleosteus was powerful and sharp, such that it was able to provide a large bite force during the closure of the jaw (Anderson and Westneat 2007). Oncorhynchus mykiss and Scleropages jardinii have the biomechanical ability to raise the lower jaw through the activity of the sternohyoid and hypohyale bones (Konow and Sanford 2008). The maxila of Lepisosteus osseus (Lepisosteidae) is extending with the ability of the jaws to close quickly and strongly (Kammerer et al. 2006). 
Keureling (Tor tambroides) is one of the freshwater fishes that has a wide distribution in the Southeast Asian region. Nevertheless, the keureling population is currently experiencing a fairly drastic decline due to overfishing, forest destruction, anthropogenic activities, fluctuations in water discharge, and land conversion (Sikder et al. 2012; Ali et al. 2013). These fish have been listed as decreasing biota and are on the Red List of the International Union for Conservation of Nature (IUCN 2018). Morphologically, keureling has a terminal mouth with pendulous skin folds that can be raised on the lips, and there are two pairs of tentacles on the upper jaw (Akmal et al. 2018b).

To date, the study of fish osteocranium is still rare compared to studies of mammals and birds (Leprevost and Sire 2014). The majority of research on keureling is still related to ecology and domestication efforts (Haryono 2006). However, a few osteological works on keureling is available. Previous studies related to the osteology of keureling are limited to general morphology and the vertebral column, while morphological information on the cranium has not published (Akmal et al. 2018a; 2018b; Zulfahmi et al. 2018). Therefore, the main aim of this present study was to describe osteocranium of keureling (Tor tambroides).

\section{MATERIALS AND METHODS}

\section{Study area}

The keureling fish used in this study obtained from the catch of fishers in the Tangse River, District of Pidie, Aceh Province, Indonesia (0502'41.48” N, 95²9'92.69” W). The fish sampled was $5 \mathrm{~kg}$ in weight, with a total length of $65 \mathrm{~cm}$ (Figure 1). Stages of research include sample preparation, bone preparations, and identification of cranium nomenclature. The cranium preparations processed at the Laboratory of Mathematics and Natural Sciences, Almuslim University, Bireuen, Indonesia. At the same time, identification of the cranium nomenclature conducted at Integrated Biology Laboratory, Faculty of Science and Technology, Universitas Islam Negeri Ar-Raniry, Indonesia.

\section{Cranium preparation}

The cranium of the keureling prepared physically and chemically. The physical stage began with separating the scalp from the bone through soaking in hot water at a temperature of $80-90^{\circ} \mathrm{C}$. The skin and connective tissue were then carefully cleaned using a scalpel. The cranium separated from the facial bones. The lower jaw separated from opercular bones, branchial bones, and the bones of the tongue and throat. All loose bones cleaned using a soft brush and tweezers. Chemical preparation began with soaking the cranium in $10 \%$ formalin for seven days, to prevent decay of cartilages. Following this, the cranium was immersed in $100 \%$ ethanol solution for 24 hours to remove water and any remaining fat attached to the bones (Taylor and Van Dyke 1985). Preserved cranium preparations were dried in the sun for seven days to produce a rigid and whitish structure. Cleansing the cranium was done using a smooth brush and then the cranium was coated with a clear transparent paint spray and dried again for three days. Any bones that separated from the others were fixed into their original positions using adhesive. Every part of the cranium photographed by using a Canon EOS 700D and photographs were edited in Adobe Photoshop CS6.

\section{Cranium nomenclature}

The nomenclature of each part of cranium determined by comparing the similarity of the shape and location of each fragment of cranium that has been studied previously by Rojo (1991), Lepiksaar (1994), Hilton and Stevenson (2013), Jalili et al. (2015a), Jalili et al. (2015b) and Nasri et al. (2016).

\section{RESULTS AND DISCUSSION}

The cranium of the keureling divided into two major regions, namely neurocranium and the branchiocranium. The neurocranium includes bones in the dermal series of the cranium and endochondral bones protecting the brain. At the same time branciocranium are those located in the oromandibular region, opercular series and branchial arch (Table 1).

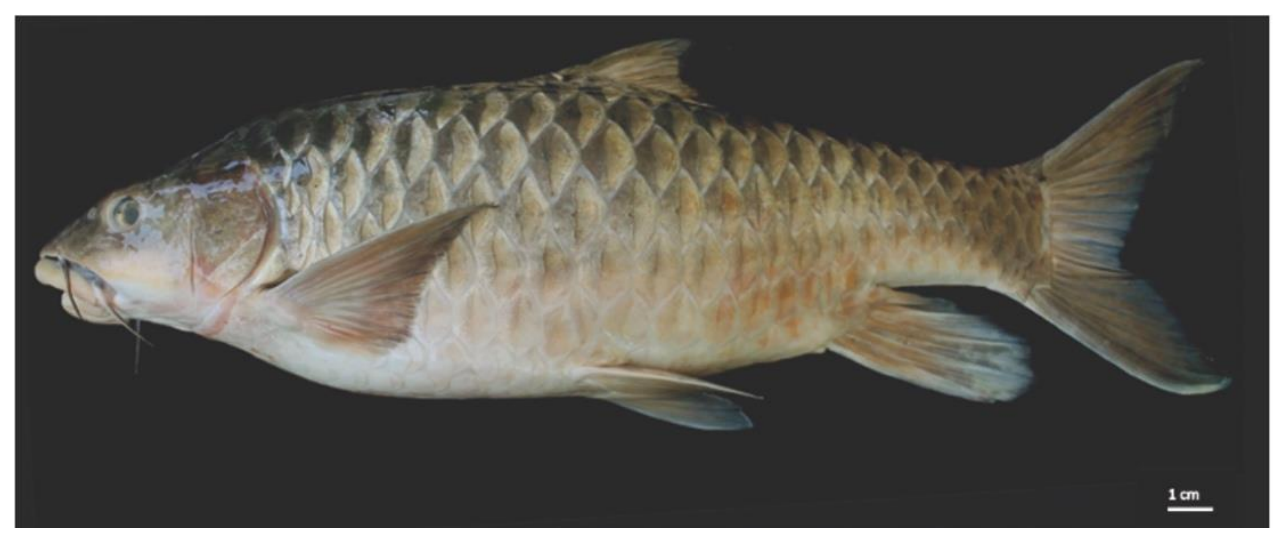

Figure 1. Lateral view of Keureling, Tor tambroides from Tangse River, Aceh, Indonesia (Scale bar: $1 \mathrm{~cm}$ ). 
Table 1. Constituent bones of the cranium of keureling, Tor tambroides

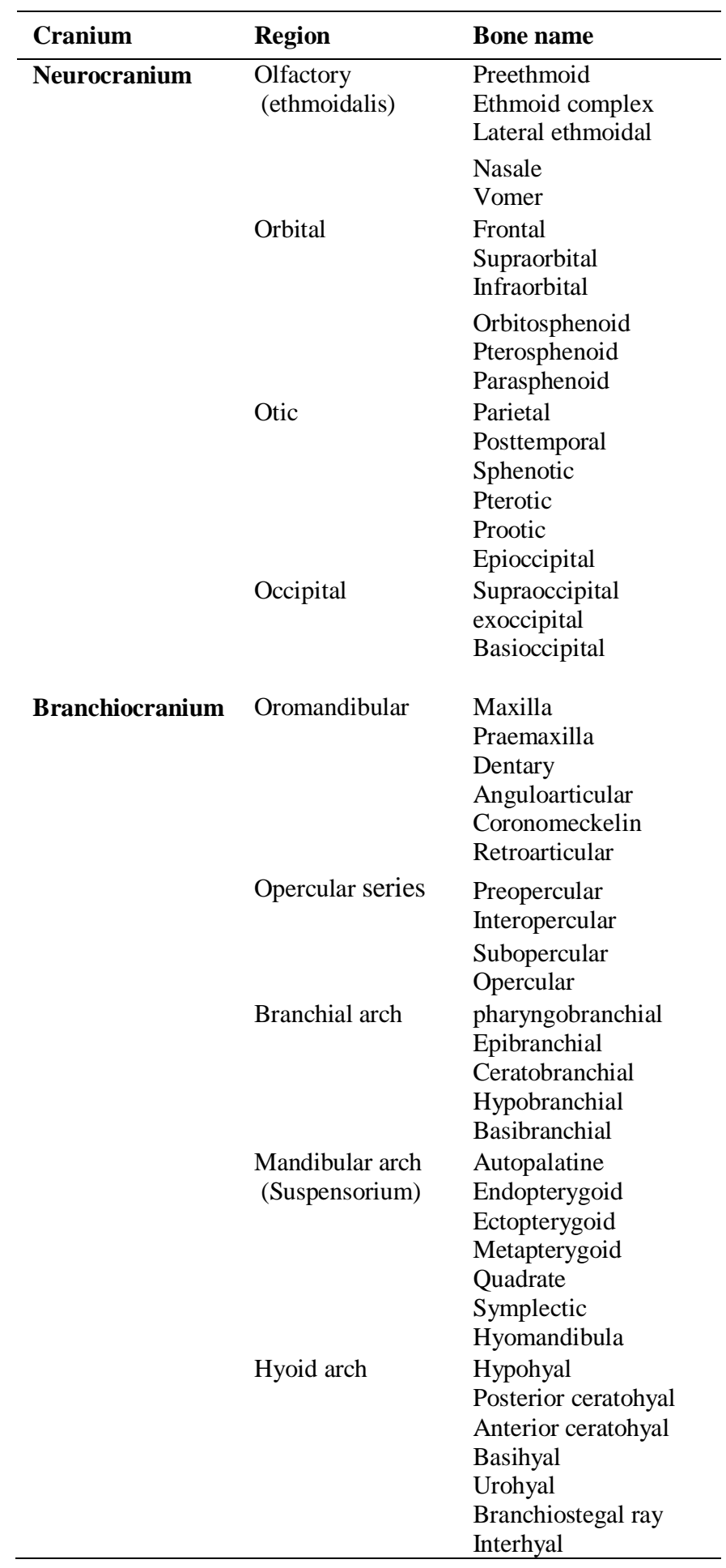

\section{Neurocranium}

The neurocranium of the keureling has a complex structure that formed from several bones that fuse to resemble a sub-triangular shape where the length of the anterior end is smaller than the posterior width. The neurocranium is divided (from anterior to posterior) into olfactory (ethmoid), orbital, otic and occipital regions
(Figures 2-6, Table 1). The olfactory region consists of the preethmoid, ethmoid complex, lateral ethmoid, nasal and vomer. The anterior aspect of the neurocranium articulates with the upper jaws. The latero-posterior aspect of it articulates with the bones of the suspensorium. The preethmoid located anteriorly, characterized by two large protrusions on the ethmoid complex (Figure 2).

The lateral ethmoid separates the ethmoid complex from the orbit. The lateral process of the lateral ethmoid is a prominent structure; it curves ventrally below the cranium roof and forms the lateral surface of the bone. The vomer located anteroventral to the parasphenoid (Figures 4 and 5). It articulates anterolaterally with the two preethmoids. The orbital region consists of the paired frontals, supraorbitals, infraorbitals, orbitosphenoids, pterosphenoids, and median parasphenoid. The frontals are the largest elements of the dorsal cranium roof. The supraorbital located on the lateral side of the frontal. It has an elongated semicircle shape. The anterior part reaches the lateral ethmoid (Figures 2, 3 and 4).

The infraorbital or circumorbital series consists of five bones that surround and hold the eyeball. The first infraorbital attaches to the lateral ethmoid by connective tissue and muscles. This bone is larger than the other infraorbitals. The third infraorbital is curved, elongated and with a sharp anterior end. The fourth infraorbital is roughly square and attaches to the posterior of the third infraorbital. The fifth infraorbital, the dermosphenotic, is the smallest of the series and has a triangular shape (Figure 3b). The orbitosphenoid and pterosphenoid were the porous bones, located in the antero-ventral part of the orbit, and contact the parasphenoid ventrally. These bones form the wall of the brain cavity and orbital foramen, where the eyeball is attached (Figure 4).

The otic region located in the posterior part of the skull and consists of the paired parietal, posttemporal, sphenotic, pterotic, prootic and epioccipital bones (Figures 2, 4 and 5). The parietal is located in the dorso-posterior part of the neurocranium. The anterior end of this bone meets the frontal, while the posterior part of the bone meets the supraoccipital. The posttemporal is a long bone that provides the attachment surface for the pectoral girdle. The sphenotic is extended ventrolaterally to the frontal. The pointed process of this bone connected to the fifth infraorbital. The pterotic meets with the medial aspect of the parietal and the lateral part of the opercular apparatus. The pterotic bears a curved facet for attachment of the hyomandibula. The anterior part of the prootic meets the sphenotic, while the posterior part meets with the basioccipital. The epioccipital located at the back of the cranium.

The occipital region of the skull connects with the vertebrae of the Weberian apparatus. This region is composed of the supraoccipital, paired exoccipitals and basioccipital (Figure 6). The supraoccipital curves posteroventrally to meet with the exoccipitals and laterally to meet the epioccipitals. The exoccipitals form the caudal aspect of the skull. These bones bear the large paired lateral occipital foramina and form the smaller foramen magnum. 
The basioccipital articulates with the first centrum of the vertebral column. The anterodorsal part of the basioccipital meets with the prootic, while the ventral aspect meets the parasphenoid. The masticatory plate of the basioccipittal protrudes from the main body of the bone and provides the attachment site for the branchial bones.

\section{Branchiocranium}

Branchiocranium is divided (from anterior to posterior) into five regions namely oromandibular, opercular series, brancial arch, mandibular arch (suspensorium) and hyoid arch (Figure 7-9 and Table 1). Bones of the oromandibular region consist of the constituent bones of the jaw namely the maxilla, premaxilla, dentary, anguloarticular, coronomeckelian and retroarticular (Figures 7 and 8). The maxilla and premaxilla comprise the upper jaw. The edentulous premaxilla is associated with a thick connective tissue that acts in feeding. The kinethmoid located between the two maxillae (Figure 7).

The dentary, anguloarticular, coronomeckelian and retroarticular comprise the lower jaw of keureling. The dentary also bears thick connective tissue that acts as substitute teeth. The anguloarticular is anterodorsal to the interopercle and articulates with the quadrate. The coronomeckelian is thin, triangular and located in the centromedial area of the dentary. At the same time, the retroarticular is a small bone at the posteroventral corner of the dentary and attaches to the interoperculomandibular ligament.

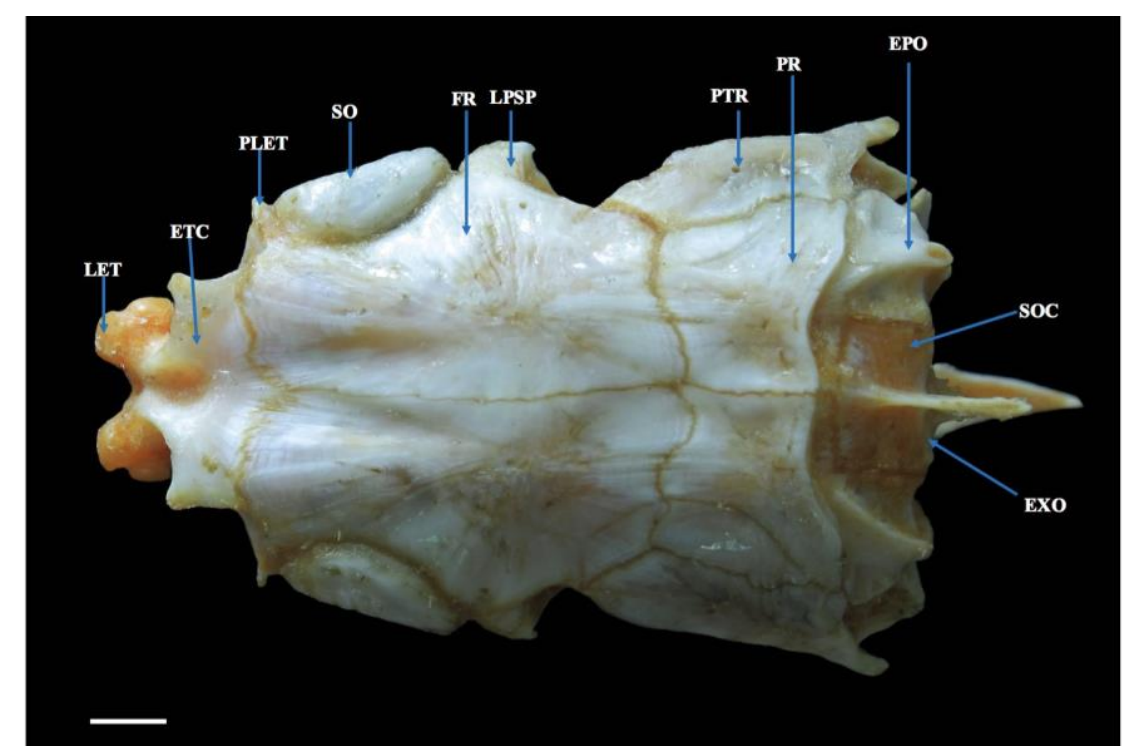

Figure 2. Dorsal view of the neurocranium. EPO: epioccipital; EXO: exoccipital; ETC: ethmoidal complex; FR: frontal; LET: lateral ethmoidal; NAS: PR: parietal; LPSP: lateral process of the sphenotic; PLET: process of the lateral ethmoid; PTR: pterotic; SO: supraorbital; SOC: supraoccipital. Scale bar: $1 \mathrm{~cm}$.
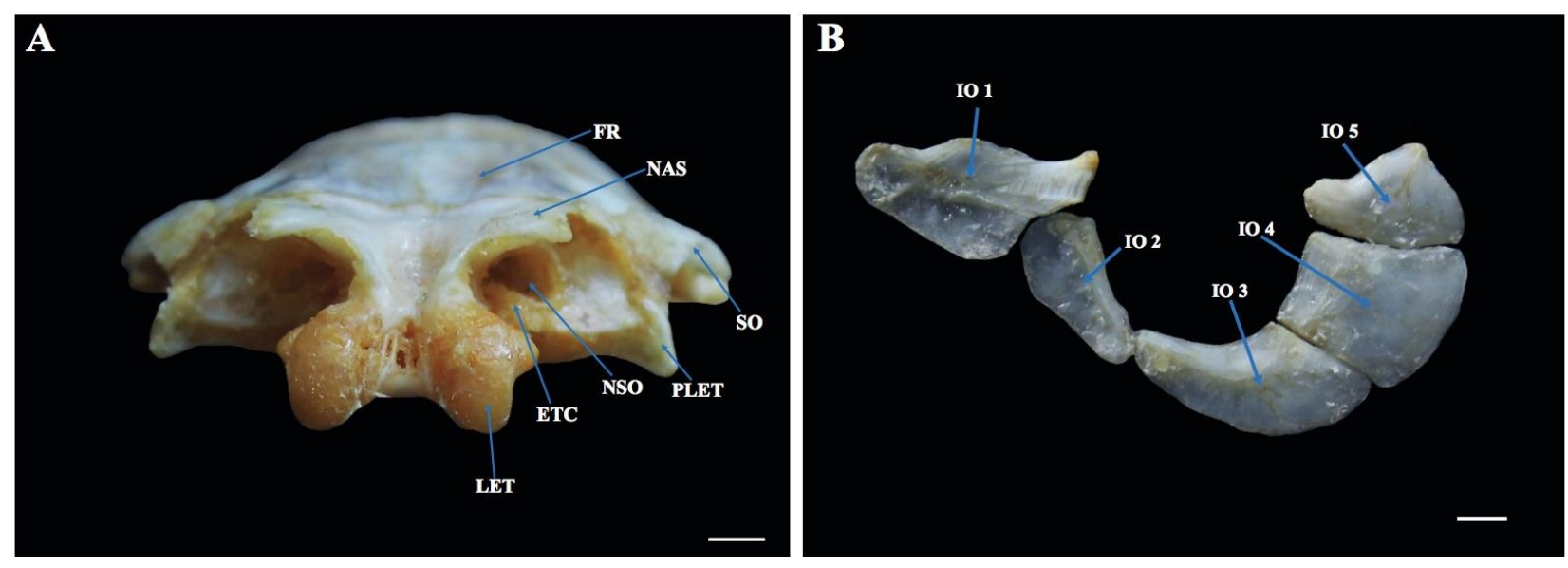

Figure 3. Anterior view of etmoidal region (A); Lateral view of infraorbital bones (B). ETC: ethmoidal complex; FR: frontal; IO 1-5: infraorbitals; LET: lateral ethmoidal; NSO: nasal opening; NAS: nasal; PLET: process of the lateral ethmoid; SO: supraorbital. Scale bar: $0.5 \mathrm{~cm}$. 


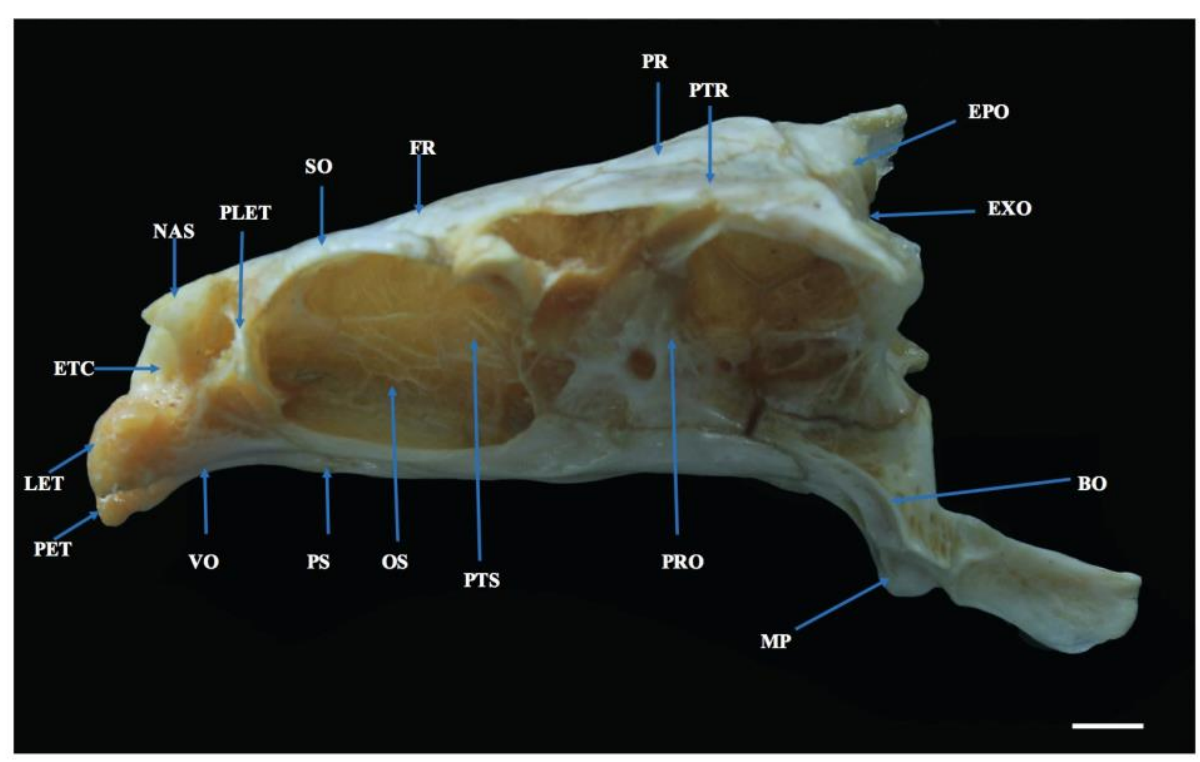

Figure 4. Lateral view of neurocranium. BO: basioccipital; ETC: ethmoidal complex; EPO: epioccipital; EXO: exoccipital; FR: frontal; LET: lateral ethmoidal; MP: masticatory plate of the basioccipital; NAS: nasale; OS: orbitosphenoidale; PLET: process of the lateral ethmoid; PET: preethmoidal; PR: parietal; PRO: prootic; PS: parasphenoid; PTR: pterotic; PTS: pterosphenoid; SO: supraorbital; VO: vomer. Scale bar: $1 \mathrm{~cm}$.

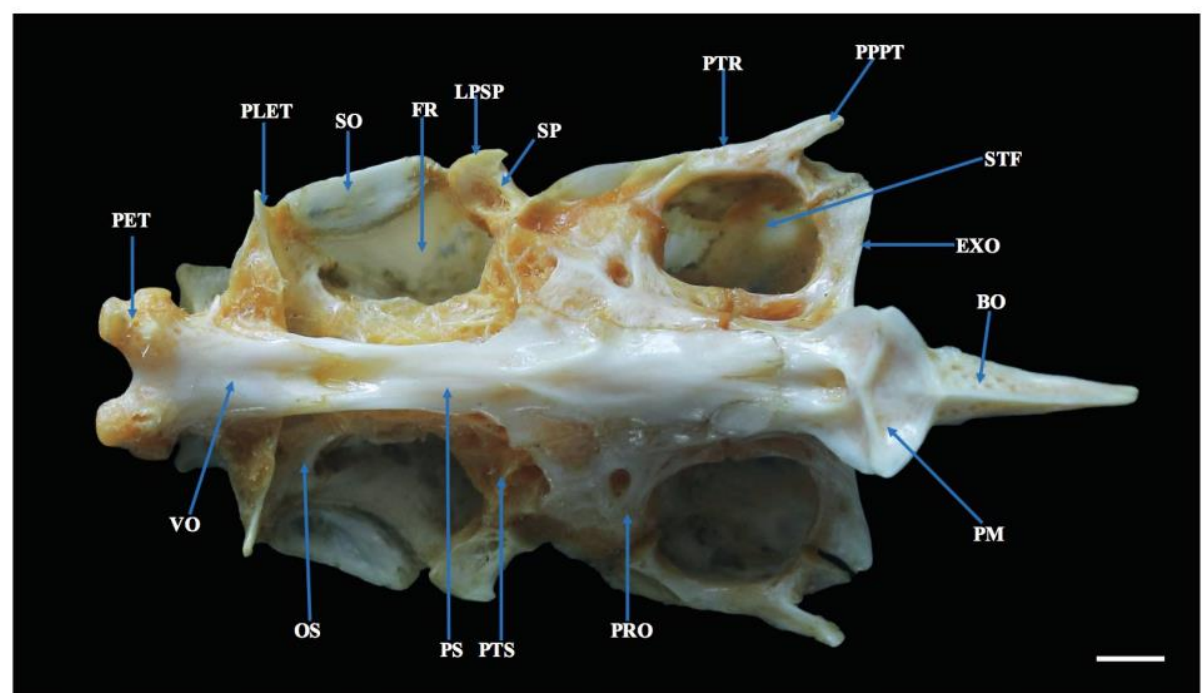

Figure 5. Ventral view of neurocranium. Keterangan: BO: basioccipital; EXO: exoccipital; FR: frontal; STF: subtemporal fossa; OS: orbitosphenoid; PET: preethmoidal; PLET: process of the lateral ethmoid; PM: masticatory plate of the basioccipital; PPPT: posterior process of the pterotic; PRO: prootic; PS: parasphenoid; LPSP: lateral process of the sphenotic; PTR: pterotic; PTS: pterosphenoid; SO: supraorbital; SP: sphenotic; VO: vomer. Scale bar: $1 \mathrm{~cm}$.

The opercular series is composed of bones that make up the protective covering of the gills. The opercular set contains four elements known as the preopercle, interopercle, subopercle and opercle (figure 8). The preopercle has a "J-like" shape that is sharp dorsally. The interopercle is the smallest bone of the series located ventral to the preopercle. The subopercle is positioned posteroventrally below the opercle. The opercle is the largest bone of the series. This bone is thin but strong and acts as the cover over the gills.

The mandibular arch or suspensorium region supported the lower jaw and opercular apparatus. This region comprises the palatine, endopterygoid, ectopterygoid, metapterygoid, quadrate, symplectic, and hyomandibula (Figure 8 ). The palatine is a long bone positioned lateral to the vomer. The posteroventral aspect of this bone meets the endopterygoid. The endopterygoid reached to below the eyeball. The ectopterygoid is thin and sharp at the tip. This bone articulates with the endopterygoid. The metapterygoid meets the quadrate and endopterygoid anteriorly, symplectic ventrally, and the hyomandibula posteriorly. The hyomandibula is the largest element and articulates with the neurocranium. The symplectic articulates between the ventral tip of the hyomandibula and the quadrate. 


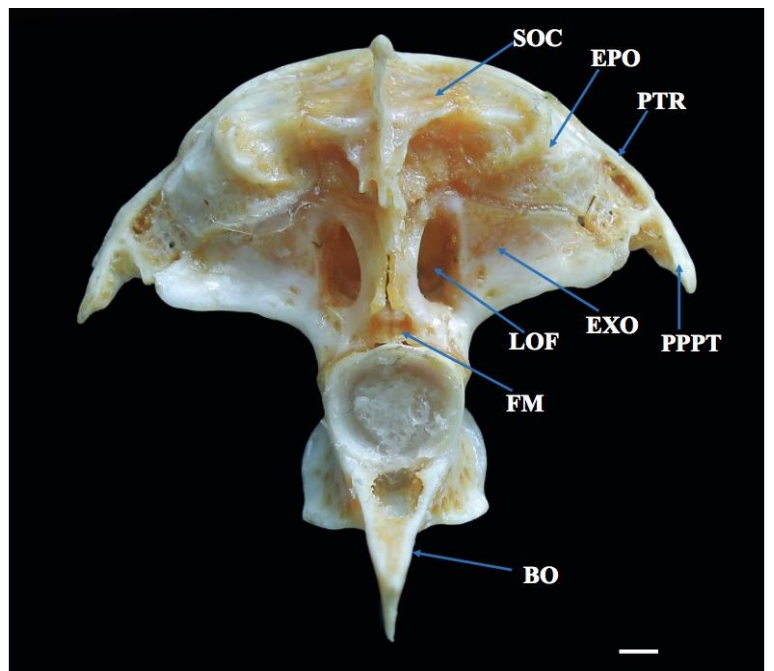

Figure 6. Posterior view of neurocranium. BO: basioccipital; EPO: epioccipital; EXO: exoccipital; FM: foramen magnum; LOF: lateral occipital foramen; PPPT: posterior process of the pterotic; PTR: pterotic; SOC: supraoccipital. Scale bar: $0,5 \mathrm{~cm}$.

The branchial arch region is composed of the pharyngobranchials, epibranchials, ceratobranchial, hypobranchials, and basibranchials (Figure 9c). There are four paired pharyngobranchials articulating with the dorsal tips of the curved epibranchials. There are five pairs of ceratobranchial bones. Four pairs are long, thin, and have a central canal, while the fifth pair modified as the lower pharyngeal jaws bearing teeth for processing the food. The hypobranchials were the short cartilages bone. This bone located at the proximal tips of the four pairs of elongate ceratobranchials. Location of the basibranchial at the median elements of the branchial arches and articulates with the hypohyals.

The hyoid region consisted of several bones that make up the ventral gill cover. The bones located in this region were the hypohyals, posterior ceratohyal, anterior ceratohyal, basihyal, urohyal, branchiostegal rays and interhyal (Figure 9a and 9b). The hypohyals, located in the anterolateral part of this region, are curved and connected with the basihyal. The posterior ceratohyal is the triangular flat bone connected with the anterior ceratohyal. The anterior ceratohyal is thick and has the branchiostegal rays attaching along the side. The basihyal and urohyal are unpaired bones, locate in the middle of the hyoid arch. The basihyal is a small cylindrical bone, while the urohyal has a triangular shape, positioned upright and connected with the hypohyals. There are three pairs of thin, long, curved branchiostegal rays. These attach to the anterior and posterior ceratohyal bones. The interhyal is a small cylindrical bone connecting the hyomandibula to the posterior ceratohyal.

\section{Discussion}

The cranium of keureling has a complex structure consisting of many elements and has multiple roles in protection and kinesis (Walter 2013; Payne et al. 2011). It provides direct protection to the brain and sensory organs. Also, the cranium plays essential role in respiration and feeding (Herbing et al. 1996, Koumoundouros et al. 2000; Löffler et al. 2008). Hilton (2011) noted that studies of the morphology of fish cranium needed to understand the development of fish evolution and ecomorphology.

The ethmoid region has a kinematic role in supporting the opening of the maxilla (Diogo et al. 2000; Ostrander and Hopkins 2000). It also acts as a chemosensory system as it houses the olfactory organ receptors located in the nostrils (Sarkar and De 2011). The ethmoid region of keureling has a form that is similar to most other cyprinid fish (Jalili et al. 2015a). The cyprinids that do not have barbels generally have a more developed process of the lateral ethmoid and nasal bone (Nasri et al. 2013; Jalili et al. 2015b). This could be influenced by the role of fish barbels as a tool to detect food, so that the lateral ethmoid process and nasal tend not to be developed. Besides, fish that use olfactory organs in foraging, such as Hoplunnis punctata (Nettastomatidae), generally have an elongate and tapered ethmoid region equipped with the olfactory fossa (Eagderi and Adriaens 2010).
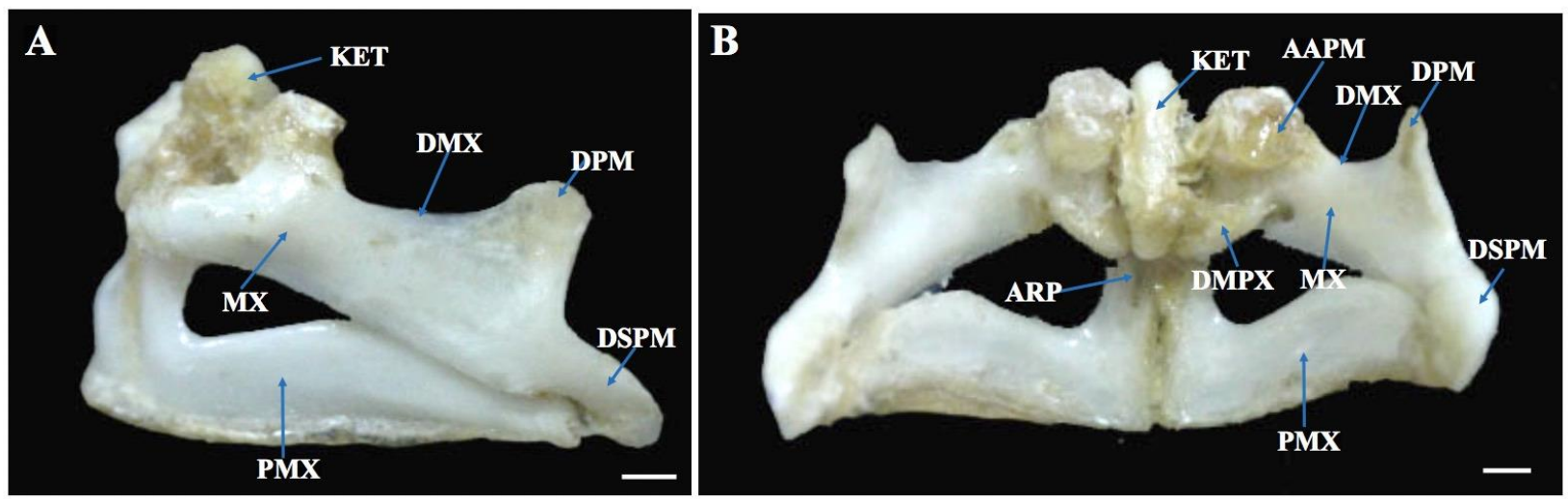

Figure 7. Lateral view of the upper jaw (A), posterior view of the upper jaw (B). KET: kinethmoid; MX: maxilla; DMX: dorsal edge of maxilla; AAPM: anterior articular process of maxilla; ARP: ascending rostral process of premaxilla; DPM: dorsal process of the maxilla; ADPM: anteroventral descending process of maxilla; DSPM: distal process of maxilla; PMX: premaxilla. Scale bar: $0,5 \mathrm{~cm}$. 


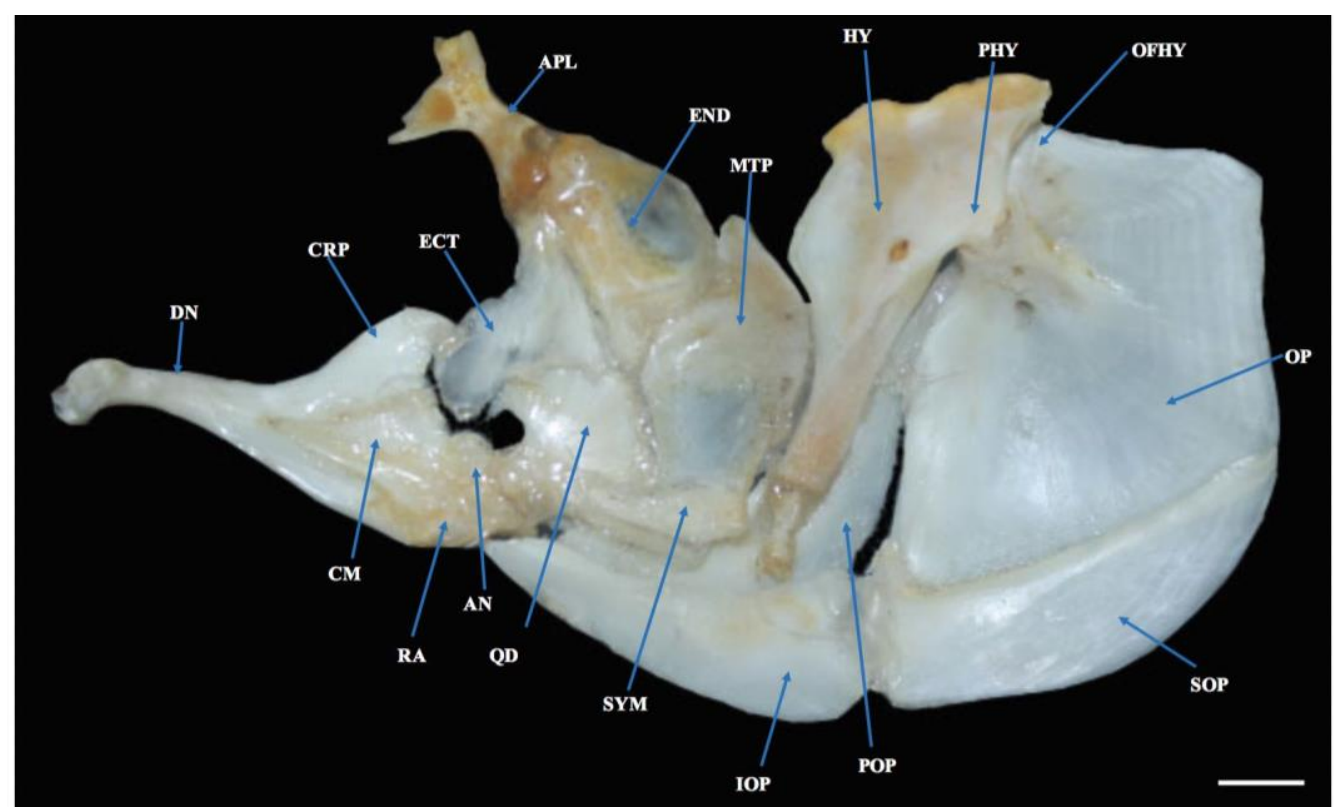

Figure 8. Medial view of the splanchnocranium, suspensorium and opercular bones, including the mandibular and hyoid arches. AN: anguloarticular; APL: autopalatine; CM: coronomeckelian; DN: dentary; ECT: ectopterygoid; END: endopterygoid; HY: hyomandibula; IOP: interopercle; MTP: metapterygoid; OP: opercle; PHY: process of the hyomandibula for articulation with the opercle; CRP: coronoid process; OFHY: opercular facet for articulation of the hyomandibula; POP: preopercle; QD: quadrate; RA: retroarticular; SOP: subopercle; SYM: symplectic. Scale bar: $1 \mathrm{~cm}$.
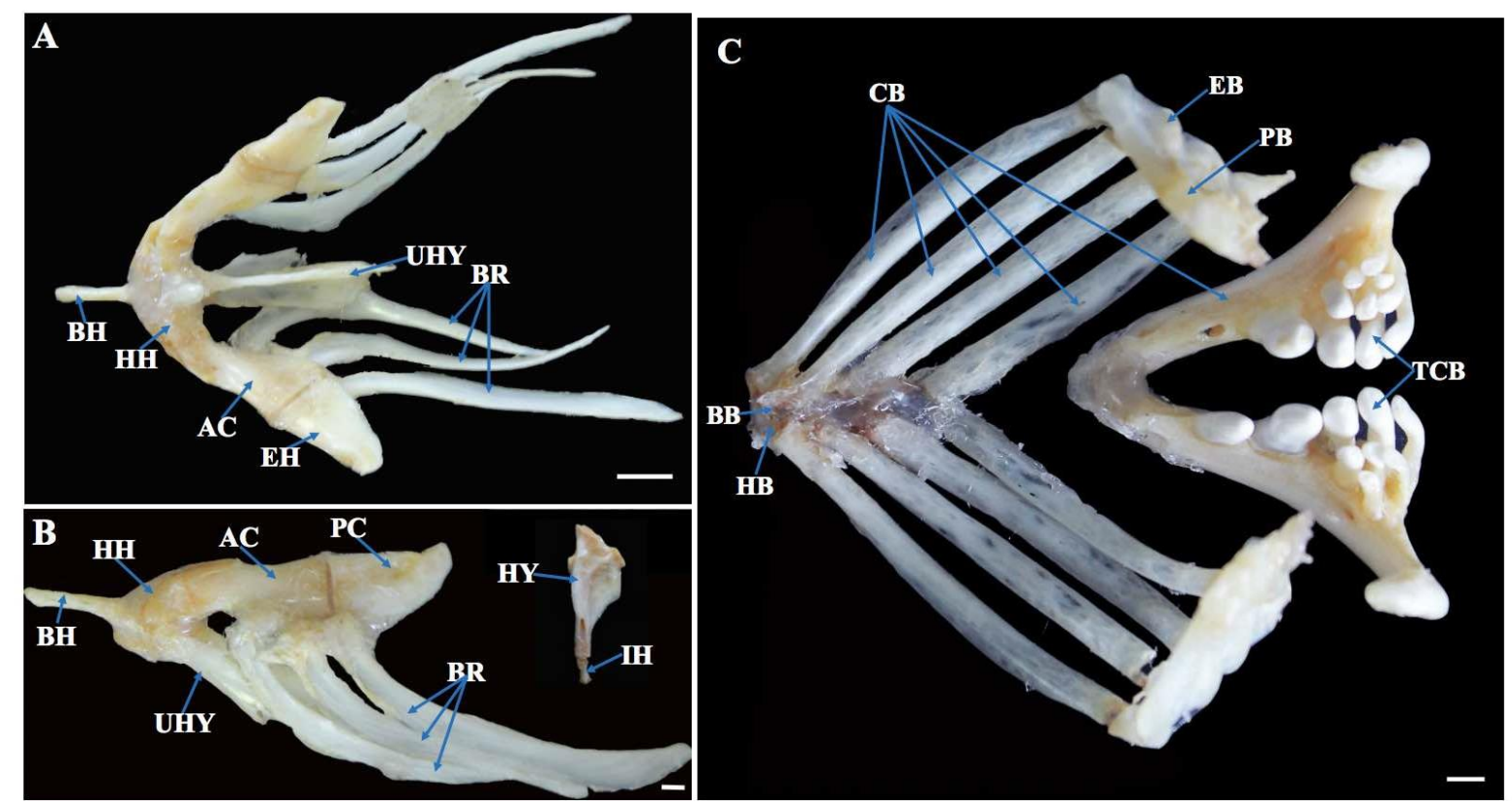

Figure 9. Dorsal view of the hyoid arch (A) lateral view of the hyoid arch (B) dorsal view of branchial arch region (C). BB: basibranchials; BH: basihyal; $\mathrm{CB}$ : ceratobranchials; AC: anterior ceratohyal; EB: epibranchials; PC: posterior ceratohyal; HB: hypobranchials; HH: hypohyal; HY: hyomandibula; IH: interhyal; PB: pharyngobranchials; TCB: teeth of the fifth ceratobranchial (lower pharyngeal jaw); BR: branchiostegal rays; UHY: urohyal. Scale bar A and B: $1 \mathrm{~cm}, \mathrm{C}: 0,5 \mathrm{~cm}$.

The orbital region plays a role in protecting the sensory organs, specifically the visual organs. Fish that forage by relying on vision had more developed orbital bones such as the infraorbitals, pterosphenoid and supraorbital (Schmitz and Wainwright 2011). The bones making up the keureling orbital region have the same shape and structure as Cyprinion milesi, but are slightly different from Barbus cyri, where the supraorbital tends to be less developed (Nasri et al 2016; Jalili et al. 2015b). The orbital regions of the keureling significantly difference in the orbital of the 
family Amiidae. The keureling has five infraorbitals in which the third infraorbital is more developed than that of Amia calva, however, the fifth infraorbital of Amia calva is more developed. Besides, the pterosphenoid and supraorbital of the keureling also appear more developed (Hilton 2011).

The otic and occipital regions play a crucial role in protecting the brain, spinal cord, and cranial nerves. Almost all fish have robust bones in these regions. There are only a few species of fish that retain cartilage elements in these regions, generally from primitive taxa such as Schindleria (Hilton 2011). In general, these regions are relatively similar to other cyprinid species such as Barbus cyri and Cyprinion milesi, although there are slight differences in the form of the posttemporal (Jalili et al. 2015b; Nasri et al. 2016).

Predatory fish such as Ariosoma gilberti (Congridae), have an otic region which tapers anteriorly and forms a spatula on the muzzle (Eagderi and Adriaens 2014). Fishes that live near the bottom of the water column, like the Amiidae, generally have otic and occipital regions that are wider posteriorly. Based on Hilton's research (2011), Amia calva had a wider parietal than the keureling and presence of an extrascapular. This thought to be an adaptation to greater water pressure on the head compared to fish that live higher in the water column.

The oromandibular, mandibular arch and hyoid arch (suspensorium) help the feeding process of fish. The kinematics of the feeding process occurs in the jaw joint. The kinematics of the feeding process occurs in the jaw joint which is supported by adductor muscles (Westneat 2003). The basic design of the oral structure has an important influence on the predation ability and diet of the fish. One common feature of the cyprinids is having a welldeveloped kinethmoid. The kinethmoid is a single median element located in the middle of the intermaxillary ligament that articulates with the maxilla (Staab and Hernandez 2010). The process of jaw kinematics in many groups of fish is affected by the performance of the premaxilla, maxilla, and kinethmoid (Drucker and Jensen 1991; Hernandez et al. 2007; Gidmark et al. 2012). In cyprinids, the kinethmoid serves as a fulcrum for opening the maxilla.

The hyoid arch and mandibular arch each play an important role in the movement of food posteroventrally through the buccal cavity (Wilga 2010; Tomita et al. 2013; Wainwright et al. 2004). In general, the shape of this region is relatively similar in cyprinid fish such as Cyprinion milesi (Nasri et al. 2016). However, the condition is different from predatory fish such as Ariosoma gilberti in the family Congridae, which has a slimmer and thinner buccal cavity (Eagderi and Adriaens 2014). The buccal cavity in predatory fish has a large size that occurs due to depression in the hyoid arch region. This serves to accommodate and engulf prey more quickly so that prey cannot escape during the capture process (Carroll et al. 2004; Van Wassenbergh and Rechter 2011).

The branchial arch region plays a vital role in supporting the fish's respiratory process (Koumoundouros et al. 2000; Saka et al. 2008). Fish that live in high oxygen waters generally have a more developed branchial arch region compared to fish that live in low-oxygen waters. There is a modification of the bones of the branchial arch region in fish that live in waters with low oxygen content including the development of pharyngobranchials into infrapharyngobranchials in Oxynoemacheilus kiabii of the family Nemacheilidae (Mafakheri et al. 2014).

The present study confirmed that the cranium of keureling divided into two major parts, namely the neurocranium and facial bones including branchial apparatus. The neurocranium is divided into (anterior to posterior) olfactory (ethmoid), orbital, otic and occipital regions while in contrast, the rest divided into oromandibular, opercular series, branchial arch, mandibular arch, and hyoid arch (suspensorium) regions. The keurling has similar morphological characteristics of the cranium compared to the rest of the family Cyprinidae but has some differences when compared to other families (Congridae, Nettastomatidae, and Nemacheilidae)

\section{ACKNOWLEDGEMENTS}

A research grant financed the study from the Center of Research and Community Service, Universitas Islam Negeri Ar-Raniry under the "Penelitian Dasar Pengembangan Program Studi" Scheme, (Reg No. 191150000015621). The authors also are grateful to Dr. Alison Murray from University of Alberta for improvement of the English language in an earlier draft of the manuscript.

\section{REFERENCES}

Aerts P. 1991. Hyoid morphology and movements relative to abducting forces during feeding in Astatotilapia elegans (Teleostei, Cichlidae). J Morphol 208 (3): 323-345.

Akmal Y, Zulfahmi I, Saifuddin F. 2018a. Karakteristik Morfometrik dan Skeleton Ikan Keureling (Tor tambroides Bleeker 1854). Jurnal Ilmiah Samudra Akuatika 2 (1): 35-44. [Indonesian]

Akmal Y, Zulfahmi I, Rahardjo MF. 2018b. Morphology of appendicular skeleton of the Thai mahseer's Tor tambroides (Bleeker, 1854). Jurnal Iktiologi Indonesia 18 (3): 261-274. [Indonesian]

Ali S, Barat A, Kumar P, Sati J, Kumar R, Haldar RS. 2013. Study of length-weight relationship and condition factor for the golden mahseer, Tor puttiora from Himalayan rivers from India. J Environ Biol 35: 225-228.

Anderson, PS, Westneat, MW. 2007. Feeding mechanics and bite force modelling of the skull of Dunkleosteus terrelli, an ancient apex predator. Biol Lett 3 (1): 77-80.

Bogutskaya NG, Naseka AM, Golovanova IV. 2008. Descriptive osteology of Gymnocorymbus ternetzi (Teleostei: Characiformes: Characidae). Zoosystematica Rossica 17 (2): 111-128.

Carroll AM, Wainwright PC, Huskey SH, Collar DC, Turingan RG. 2004. Morphology predicts suction feeding performance in centrarchid fishes. J Exp Biol 207 (22): 3873-3881.

Cooper WJ, Westneat MW 2009. Form and function of damselfish skulls: rapid and repeated evolution into a limited number of trophic niches. BMC Evol Biol 9 (1): 9-24.

De Iuliis G, Pulerà D. 2011. The dissection of vertebrates, Second Edition A Laboratory Manual. Academic Press. Pp.79-82

Deschamps MH, Sire JY. 2010. Histomorphometrical studies of vertebral bone condition in farmed rainbow trout, Oncorhynchus mykiss. J Appl Ichthyol 26 (2): 377-380. 
Dierickx K, Wouters W, Van Neer W. 2017. Comparative osteological study of three species of distinct genera of Haplotilapiin (Cichlidae). Cybium 41 (3): 223-235.

Diogo R, Oliveira C, Chardon M. 2000. On the anatomy and function of the cephalic structures in Phractura (Siluriformes: Amphiliidae), with comments on some striking homoplasies occurring between the Doumeinae and some loricaroid catfishes. Belgian J Zool 130 (2): 117-130.

Drucker EG, Jensen JS. 1991. Functional analysis of a specialized prey processing behavior: winnowing by surfperches (Teleostei Embiotocidae). J Morphol 210: 267-287.

Eagderi S, Adriaens D. 2014. Cephalic morphology of Ariosoma gilberti (Bathymyrinae: Congridae). Iranian J Ichthyol 1 (1): 39-50.

Eagderi S, Adriaens D. 2010. Head morphology of the duckbill eel, Hoplunnis punctata (Regan, 1915; Nettastomatidae: Anguilliformes) in relation to jaw elongation. Zoology 113 (3): 148-157.

Ferry-Graham LA, Lauder GV. 2001. Aquatic prey capture in ray-finned fishes: a century of progress and new directions. J Morphol 248 (2): 99-119.

Fugi R, Agostinho AA, Hahn NS 2001. Trophic morphology of five benthic-feeding fish species of a tropical floodplain. Revista Brasileira de Biologia 61 (1): 27-33.

Gidmark NJ, Staab KL, Brainerd EL, Hernandez LP. 2012. Flexibility in starting posture drives flexibility in kinematic behavior of the kinethmoid-mediated premaxillary protrusion mechanism in a cyprinid fish, Cyprinus carpio. J Exp Biol 215 (13): 2262-2272.

Haryono. 2006. Aspek biologi ikan tambra (Tor tambroides Bleeker, 1854) yang eksotik dan langka sebagai dasar domestikasi. Biodiversitas 7 (2): 195-198. [Indonesian]

Herbing IHV, Miyake T, Hall BK, Boutilier RG. 1996. Ontogeny of feeding and respiration in larval Atlantic cod Gadus morhua (Teleostei, Gadiformes): I. Morphology. J Morphol 227 (1): 15-35.

Hernandez LP, Bird NC, Staab KL. 2007. Using zebrafish to investigate cypriniform evolutionary novelties: functional development and evolutionary diversification of the kinethmoid. J Exp Zool B 308: 625-641.

Hilton EJ, Stevenson DE. 2013. Osteology of the Prowfish, Zaprora silenus (Cottiformes: Zoarcoidei: Zaproridae). J Morphol 274 (10) 1143-1163.

Hilton EJ. 2011. The Skeleton Bony Fish Skeleton. Elsevier Inc., USA

Hilton EJ, Kley NJ. 2005. Osteology of the Quillfish, Ptilichthys goode (Perciformes: Zoarcoidei: Ptilichthyidae). Copeia 2005 (3): 571-585.

IUCN. 2018. IUCN Red List of Threatened Animals. IUCN, Gland and Cambridge.

Jalili P, Eagderi S, Nasri M, Mousavi-Sabet H. 2015a. Descriptive osteology study of Alburnus amirkabiri (Cypriniformes: Cyprinidae) a newly described species from namak lake basin, central of Iran. Bull Iraq Nat Hist Mus 13 (4): 51-62.

Jalili P, Eagderi S, Nikmehr N, Keivany Y. 2015b. Descriptive osteology of Barbus cyri (Teleostei: Cyprinidae) from southern Caspian Sea basin. Iranian J Ichthyol 2 (2): 105-112.

Kammerer CF, Grande L Westneat MW. 2006. Comparative and developmental functional morphology of the jaws of living and fossi gars (Actinopterygii: Lepisosteidae). J Morphol 267 (9): 1017-1031.

Konow N, Sanford CP. 2008. Biomechanics of a convergently derived prey-processing mechanism in fishes: evidence from comparative tongue bite apparatus morphology and raking kinematics. J Exp Biol 211 (21): 3378-3391.

Koumoundouros G, Divanach P, Kentouri M. 2000. Development of the skull in Dentex dentex (Osteichthyes: Sparidae). Mar Biol 136 (1): 175-184.

Lepiksaar J. 1994. Introduction to Osteology of Fishes For Paleozoologists. Göteborg. 61-79p.

Leprevost A, Sire JY. 2014. Architecture, mineralization and developmen of the axial skeleton in Acipenseriformes, and occurrences of axial anomalies in rearing conditions; can current knowledge in teleost fish help? J Appl Ichthyol 30 (4): 767-776

Löffler J, Ott A, Ahnelt H, Keckeis H. 2008. Early development of the skull of Sander lucioperca (L.) (Teleostei: Percidae) relating to growth and mortality. J Fish Biol 72 (1): 233-258.

Mafakheri P, Eagderi S, Farahmand H, Mousavi-Sabet H. 2014. Osteological structure of Kiabi loach, Oxynoemacheilus kiabii (Actinopterygii: Nemacheilidae). Iranian J Ichthyol 1 (3): 197-205.

Murray AM. 2004. Osteology and morphology of the characiform fish Alestes stuhlmannii (Alestidae) from the Rufiji River basin, East Africa. J Fish Biol 65 (5): 1412-1430.

Nasri M, Eagderi S, Farahmand H. 2016. Descriptive and comparative osteology of Bighead Lotak, Cyprinion milesi (Cyprinidae: Cypriniformes) from southeastern Iran. Vertebr Zool 66 (3): 251-260.

Nasri M, Keivany Y, Dorafshan S. 2013. Comparative osteology of lotaks, Cyprinion kais and C. macrostomum (Cypriniformes, Cyprinidae), from Godarkhosh River, western Iran. J Ichthyol 53 (6): 455-463.

Ostrander GK, Hopkins J. 2000. The Laboratory Fish. Academic Press, San Diego.

Payne SL, Holliday CM, Vickaryous MK. 2011. An osteological and histological investigation of cranial joints in geckos. Anatomical Record: Adv Integr Anatomy Evol Biol 294 (3): 399-405.

Rojo AL. 1991. Dictionary of Evolutionary Fish Osteology. CRC Press, Boca Raton.

Saka, Ş, Çoban D, Kamacı HO, Süzer C Fırat K. 2008. Early development of cephalic skeleton in hatchery-reared gilthead seabream, Sparus aurata. Turkish J Fish Aquat Sci 8 (2): 341-345.

Sarkar SK, De SK. 2011. Functional morphoanatomy of olfactory sensory epithelial cells of Pseudapocryptes lanceolatus (Bloch and Schneider). Intl J Sci Nat 2 (2): 1-6.

Schmitz L, Wainwright PC. 2011. Ecomorphology of the eyes and skull in zooplanktivorous labrid fishes. Coral Reefs 30 (2): 415-428.

Sikder MT, Yasuda M, Yustiawati, Syawal SM, Saito T, Tanaka S, Kurasaki M. 2012. Comparative Assesment on water quality in the major rivers of Dhaka and West Java. Intl J Environ Prot 2 (4): 8-13.

Staab KL, Hernandez LP. 2010. Development of the Cypriniform protrusible jaw complex in Danio rerio: constructional insights for evolution. J Morphol 271: 814-825.

Takeuchi H, Hosoya K. 2011. Osteology of Ischikauia steenackeri (Teleostei: Cypriniformes) with comments on its systematic position. Ichthyol Res 58 (1): 10-18.

Taylor WR, Van Dyke CC. 1985. Revised procedures for staining and clearing small fishes and other vertebrates for bone and cartilage study. Cybium 9: 107-119.

Tomita T, Toda M, Yamamoto Y, Sato K, Uchida S, Nakaya K. 2013. A novel pharyngeal expansion mechanism in the yellow-spotted fanray, Platyrhina tangi (Elasmobranchii: Batoidea), with special reference to the function of the fifth ceratobranchial cartilage in batoids. Zoomorphology 132 (3): 317-324.

Van Wassenbergh S, De Rechter D. 2011. Piscivorous cyprinid fish modulates suction feeding kinematics to capture elusive prey. Zoology 114 (1): 46-52.

Wainwright PC, Bellwood DR, Westneat MW, Grubich JR, Hoey AS 2004. A functional morphospace for the skull of labrid fishes: patterns of diversity in a complex biomechanical system. Biol J Linn Soc 82 (1): 1-25.

Walter BE. 2013. Cranial skeletogenesis and osteology of the redeye tetra Moenkhausia sanctaefilomenae. J Fish Biol 82: 69-95.

Westneat MW. 2003. A biomechanical model for analysis of muscle force, power output and lower jaw motion in fishes. J Theor Biol 223 (3): 269-281.

Wilga CD. 2010. Hyoid and pharyngeal arch function during ventilation and feeding in elasmobranchs: conservation and modification in function. J Appl Ichthyol 26 (2): 162-166.

Zulfahmi I, Akmal Y, Batubara AS. 2018. The morphology of Thai mahseer's Tor tambroides (Bleeker, 1854) axial skeleton (ossa vertebrae). Jurnal Iktiologi Indonesia 8 (1): 35-44. [Indonesian] 